\title{
Title Sponsorship of Cause-Related Sport Events
}

\begin{tabular}{|r|l|}
\hline Journal: & Sport, Business, Management: an International Journal \\
\hline Manuscript ID & SBM-04-2018-0034.R2 \\
\hline Manuscript Type: & Research Paper \\
\hline Keywords: & $\begin{array}{l}\text { Sponsorship, Cause-Related Marketing, Not-For-Profit, Event Management, } \\
\text { Canada }\end{array}$ \\
\hline \multicolumn{2}{|l}{} \\
\hline
\end{tabular}

\section{SCHOLARONE \\ Manuscripts}


Running head: Title Sponsorship

\section{Title Sponsorship of Cause-Related Sport Events}

Date: August 19, 2018

\section{Acknowledgements:}

We would like to thank Elio Antunes and Tala Chulak-Bozzer for their support of this research. Guy Faulkner holds a Canadian Institutes of Health Research-Public Health Agency of Canada (CIHR-PHAC) Chair in Applied Public Health. Amy Latimer-Cheung receives support from the Canada Research Chairs Program.

\section{Keywords}

Sponsorship, Cause-Related Marketing, Not-For-Profit, Event Management, Canada 
Running head: Title Sponsorship

\section{Title Sponsorship of Cause-Related Sport Events}

Corporate sponsorship of any property has increased globally year-over-year for more than two decades (IEG, 2016), with similar growth reported in Canada (CSLS, 2018). On the corporate brand side, sponsorship is a key element of their marketing mix (Walraven et al., 2016). In Canada, for example, sponsors report spending more than $20 \%$ of their marketing communication dollars on sponsorship related activities (i.e., rights fees plus activation) with more than $60 \%$ of sponsorship rights fees invested by both sport and non-sport corporations going to sport properties (Berger et al, 2008; CSLS, 2018). Not-for-profit organizations (NFPs) in sport (i.e., leagues, events, clubs) have adopted sponsorship as an important revenue generation tool (Berger et al, 2008; Meenaghan, 2013).

Corporate sponsors are increasingly interested in associating with cause-related sport events organized or founded by NFPs that address causes which resonate with their customers (Babiak \& Sheth, 2010). Notably, title sponsorship is one important type of sponsorship that has received limited research attention. Title sponsorship is where the partner is given top-level naming rights to a cause-related sport event. Typically, it is the most expensive sponsorship category. Examples of cause-related sporting events that boast title sponsors are Dick's Sporting Goods Open ${ }^{1}$, Wendy's Walk for Kids ${ }^{2}$, Hershey's Track and Field Games ${ }^{3}$, Nike's Clash of Champions, and the Susan G. Komen Race for the Cure ${ }^{4}$. In the NFP sport event context, it is important to recognize that seeking title sponsorship is challenging. This is why, many NFP sport

\footnotetext{
${ }^{1}$ See Endicott (n.d.) DICK'S Sporting Goods Open. Retrieved from the World Wide Web on January 14, 2017 : http://together.pgatour.com/tournaments/s008.html. NY: New York.

${ }^{2}$ See Wendy's Walk for Kids. (2017). Homepage. Retrieved from the World Wide Web on January 14, 2017: http://wendyswalkforkids.com.

${ }^{3}$ See Run Jump Throw (n.d.). Hershey's Games 101. Retrieved from the World Wide Web on January 14, 2017: https://www.hersheystrackandfield.com/about/hersheys-games-101.aspx.

${ }^{4}$ See Susan G. Komen (2017). Susan G. Komen Race for the Cure. Retrieved from the World Wide Web on January 14, 2017: http://ww5.komen.org/findarace.aspx.
} 
Running head: Title Sponsorship

events occur without a title sponsor (Groza, Cobbs \& Schaefers, 2012). For example, the majority of Disabled Sports USA (2015) events take place without a title sponsor. A key driver of the lack of title sponsors is the need for the evaluation of the ability of the sponsorship to drive consumer awareness and generate return on its investment (PriceWaterhouseCoopers, 2010), as well as garner support to the cause (Madill \& O’Reilly, 2010).

Title sponsorship differs from other levels of sponsorship. First, the 'title' status typically has a higher cost to the sponsor than other sponsor levels and, in turn, increased financial importance for the NFP (Clark, Cornwell \& Pruitt, 2008). This may lead to increased commitment of the organizations and pressure to evaluate and support the achievement of returnon-investment for the title sponsor (Groza, Cobbs \& Schaefers, 2012; O’Reilly \& Madill, 2012). Second, since the cause-related objectives are sought by both the title sponsor and the NFP organization, such objectives can be more complicated than for a partnership between two forprofit-based organizations, since the NFP organisation may struggle to embrace the profit motivations of the sponsor (Madill \& O’Reilly, 2010). For example, RiskVentures (2014), an equity/consulting firm sponsored a golf event put on by Operation Game On, an innovative rehab program for returning combat-injured troops, as part of its philanthropy strategy. Conversely, Bridgestone Tires' title sponsorship ${ }^{5}$ of the National Hockey League's (NHL) outdoor event (game) known as the Winter Classic, involves two organizations with clear business objectives.

Third, as the title sponsor of a cause-based sport event, the sponsor associates itself with the event of interest, the NFP as well as the cause. For instance, if the event was a charity run for diabetes research, the title sponsor would be associating with the run, the NFP, and the cause of disease prevention and cure. This increases complexity, as the sponsor would want to achieve the

\footnotetext{
${ }^{5}$ See NHL (2015). Bridgestone returns as title sponsor of NHL Winter Classic in five-year partnership renewal with NHL. Retrieved from the World Wide Web on January 14, 2017: https://www.nhl.com/news/bridgestone-returnsas-title-sponsor-of-nhl-winter-classic-in-five-year-partnership-renewal-with-nhl/c-775909
} 
Running head: Title Sponsorship

business objectives and, in most cases, support the pursuit of the objectives supporting the cause (Madill \& O'Reilly, 2010). Fourth, due to the close association between the title sponsor and the event, the ability to transfer images (a known benefit of sponsorship) is facilitated more than other forms of sponsorships (Gwinner, Larson \& Swanson, 2009). In general, an image transfer occurs via marketing when attributes of the event are expected to be transferred to the sponsor via the activation of the sponsorship between the two entities, resulting in the event image "rubbing off" on the sponsor (Grohs \& Reisinger, 2014). A classic example of this is Gatorade's longstanding sponsorship activities in the sport of triathlon which has aided in attributing images of athlete endurance to the energy drink brand.

The current empirical study seeks to address the topic of title sponsorship in cause-related sport events by answering the following research questions: (i) how does the title sponsorship of a cause-related sport event influence evaluations of the corporation? (ii) how do consumer evaluations of the title sponsor compare with other sponsors, the NFP, the cause, and the event? and (iii) how does the title sponsorship by a corporation influence the evaluations of other sponsors, the NFP, the cause, and the event? Due to the limited research on the topic, exploratory approach is undertaken in the form of an in-depth empirical study based on multiple data collections around a re-occurring annual event (see Neuman, 2011; Yin 2003) to answer these research questions. The study reviews a cause-related sport event spread over multiple years where a title sponsor was added during the period of the research. Implications on awareness levels among both the general Canadian population and the target market (event organizers) were measured over the multi-year period and assessed for the title sponsor, secondary sponsors, other partners, the cause, and the NFP that was the rights holder for the event.

\section{Research Context}


Running head: Title Sponsorship

The program that is the context for this research is RBC Sports Day in Canada (SDIC), a series of events where communities come together nationally to celebrate sport among Canadians and to promote sport participation across Canada. SDIC was developed by ParticipACTION, a national NFP dedicated to increasing physical activity among Canadians (Latimer, Murumets, \& Faulkner 2014). SDIC could be described as an 'event of events'. It takes place at the end of a week of thousands of local sporting events and activities and includes a day-long national television broadcast. SDIC was held annually between 2010 and 2015, usually in November. Leading up to the day of the main event, local organizations, communities and schools across the country celebrate sport at the local level and help build momentum for SDIC by participating in thousands of registered open houses, games, competitions, meet-and-greets, tournaments, fun runs, spectator events, and pep rallies. ParticipACTION sends promotional materials to each registered event organizing team and lists events on their website. Previous longitudinal research on SDIC found significant increases over time in awareness of SDIC for the Canadian population (White et al., 2016) and that many of the participating organizations benefited from hosting a SDIC event (Luciani et al., 2016).

In terms of title sponsorship, ParticipACTION ${ }^{6}$ acquired RBC Bank in 2013 , the $4^{\text {th }}$ year of SDIC, for a 3-year term. A portion of the RBC title sponsorship allowed ParticipACTION to provide grants to select NFPs to support events as part of SDIC. SDIC fits Yin's (2003) requirements for a case study because it is significant (i.e., impacted the cause across the country per point below), complete (i.e., multi-year event with full implementation), and displayed sufficient evidence of success. To provide evidence of success, SDIC achieved awareness levels of $47 \%$ of Canadian citizens in 2013 and 44\% in 2015 (Sports Day, 2016), and more than 60

\footnotetext{
${ }^{6}$ See ParticipACTION. Homepage. Retrieved January 14, 2017 from the World Wide Web: https://www.participaction.com/en-ca/about for more detailed information.
} 
Running head: Title Sponsorship

million media impressions in 2013 (White et al., 2016) and more than 85 million in 2015 (Sports Day, 2016).

\section{Literature Review and Hypotheses Development}

\section{Sponsorship}

Sponsorship generally contains two distinct elements: 1) the mutually beneficial exchange of sponsor resources in return for promotional value and 2) the sponsor's association with the property (Meenaghan, 2013). Sponsorship continues to be an important part of marketing. IEG (2016) reports that there was an increase in global sponsorship rights spending from 2012 to 2015, with an annual industry spend nearing US\$60 billion. In Canada, the CSLS (2018) reports an estimated total industry spend on rights fees of more than CDN\$1.96 billion in 2016, up from CDN\$1.1 billion in 2007. The scale of sponsorship spending around major events is also significant. For example, sponsors of the 2012 London Olympic Summer Games spent a combined US\$2 billion around the event (Meenaghan, 2013).

Discussions regarding the differences between sponsorship and other forms of marketing communications, specifically advertising, are ongoing. Meenaghan (2013) notes that the main differences are "the mutuality of benefit, the consumer interaction process, the comparative nature of the consumer interaction process, and the sponsorship's location at the leisure end of marketing" (p.388). It is commonly believed that due to its interactive nature, sponsorship is valued higher than traditional advertising. Advantages of sponsorship over more common forms of marketing include the opportunity to differentiate from competitors, to achieve consumeroriented objectives, and to achieve competitive advantage (Madill \& O’Reilly, 2010).

While traditional sponsorship remains important, many scholars now view sponsorship in a more widespread, digital and strategic way (Meenaghan, 2013), such as building social media 
Running head: Title Sponsorship

campaigns or creating owned properties. Sponsorship as a marketing tool is complex, as its influence is dependent upon several variables including "the demographics of the audience, the product category of the sponsor, and the type of activations used to support the partnership and the communication used to 'framework' the sponsorship message” (Pearsal, 2009, p. 25).

Title Sponsorship

Title sponsorship includes the sponsor's name in the name of the event (Groza, Cobbs \& Schaefers, 2012). While the empirical study specific to the case of title sponsorship is limited, corporate sponsor behaviour (i.e., higher levels of financial investment in title sponsorship status) suggests that they are interested in title sponsorship in the sports industry (CSLS, 2016). Title sponsorship is the highest form of sponsorship garnering top media coverage and known for generating both brand and product awareness (Clark, Cornwell \& Pruitt, 2008), through advertising and publicity (Bicaia et al., 2013). Although very similar in nature and often used interchangeably, title sponsorship is commonly categorized for an event (e.g., RBC Sport Day in Canada) while naming rights sponsorship is for a venue (e.g., the Fuqua School of Business, Duke University) or another tangible item (e.g., the John R. Wooden Award). Like title sponsorship, previous empirical research on the naming rights of venues is also limited (Delia, 2014).

\section{Cause-Related Marketing (CRM)}

Polansky and Speed (2000) define CRM as "the process of formulating and implementing marketing activities that are characterized by an offer from the firm to contribute a specified amount to a designated cause when consumers engage in revenue-providing exchanges that satisfy organizational and individual objectives" (p. 1365). However, these transaction-based CRM partnerships have over time evolved into more strategic alliances (including sponsorships 
Running head: Title Sponsorship

and title sponsorships), where financial contribution is still considered central to the conditions of contract, but less tied to consumer actions of purchasing the brand (Gourville \& Rangan, 2004). Financially significant relationships between corporations and NFP organisations have increased in recent years (Simpson, Lefroy \& Tsarenko, 2011) due to reduced or inconsistent funding from the government, leading NFP organisations to seek corporate entities as a funding source (Navarro, 2005), such as title sponsorship of a cause-related sport event, where the support of the sponsor will be positively viewed. The related literature reveals a growing trend towards cause-related marketing (Rozensher, 2013). When price and value are comparable, consumers tend to buy brands associated with CRM (Irmak, Jayachandran \& Robinson, 2012; CCSIS, 2013). Up from $85 \%$ in 2010 , in $2013,93 \%$ of U.S. consumers said that when a company supports a cause, they have a more positive image of the company (CCSIS, 2013). A Canadian study similarly showed that consumers favor ethical products and socially responsible companies (d'Astous \& Legendre, 2008). This leads to the first hypothesis to be tested: H1: The corporation will receive positive evaluations as a title sponsor of a cause-related sport event.

Lacey, Close and Finney (2010) found that consumer perceptions of the sponsor as socially responsible are positively linked to commitment and purchase intentions. Marketing opportunities involving social needs (e.g., including benefits towards a societal need such as poverty) can assist companies as they differentiate and reposition their brands to increase their return (Lii, Wu \& Ding, 2011). CRM is also expected to have a positive effect on consumers' attitudes toward the brand and the perceived credibility of the campaign (Lii, Wu \& Ding, 2011). However, consumers also want to know what cause-related activities companies are aligning their brand with. In other words, it is critical that consumers perceive a fit between the (title) 
Running head: Title Sponsorship

sponsor and the property, as they respond more positively when there is good fit (Polonsky \& Speed, 2000), which would include a link to an appropriate cause.

As Cone (2013) notes, corporations and brands today cannot just be responsive, they must also be responsible. CRM is ubiquitous in our environment and it plays a vital role in the way a brand is perceived by consumers. The same could be said for title sponsorship of a causerelated event. Indeed, CRM serves dual purposes: to improve firm performance and to support a social cause (Irmak, Jayachandran \& Robinson, 2012). To improve a sponsor's performance, there must be a relationship between the brand and the cause. Further, they should have shared objectives, sponsor-property fit, and goal proximity; each of which influences consumers' perceptions or personal roles in helping the cause (Irmak, Jayachandran \& Robinson, 2012). To achieve maximum influence on consumer perceptions, firms must be more forthcoming and share with consumers why and how they are involved in socially responsible activities. Notably, consumers must have a clear sense of the sponsor's role and the ability to drive positive change (CCSIS, 2013). This leads to the second hypothesis.

$\mathrm{H} 2$ : The Corporation who is a title sponsor will enhance the evaluations of (a) the cause-related event and (b) the cause.

Sponsorship Evaluation

Authors of previous research note the significant challenge that surrounds the evaluation of sponsorship (O’Reilly \& Madill, 2012). According to Sponsorship Works (2007), many early sponsorship evaluations relied on awareness metrics, which is still the case today and may not be a good indicator of the objectives that most sponsors seek to achieve from sponsorship, including attitude changes and brand purchase (Biscaia et al, 2014; Lee, Harris \& Lyberger, 2011; Nufer \& Bühler, 2010). 
Running head: Title Sponsorship

Most of the literature on sponsorship evaluation related to awareness is tied directly to a specific event, often a sport event. Biscaia et al. (2014) define brand awareness as the consumers' familiarity with a brand and note that sponsorship creates another outlet for companies to create more awareness of their brand(s). Creating a synonymous relationship between a cause and a brand through sponsorship can create both positive and negative awareness for the brand (Madill \& O'Reilly, 2010). To improve brand awareness and awareness that the sponsor is doing 'good', businesses must understand how to communicate with consumers. The top three most effective communication routes to best create this awareness for information about social and environmental programs and products are via the product, media, and advertising (CCSIS, 2013) and industry research tells us that sponsors want a clean (exclusive) platform to activate and pursue their objectives (CSLS, 2016; 2018). Title sponsorship can provide for each of these programs, products and activations. As sponsor involvement increases with activations (and, by extension, via title sponsorship status) so does consumer awareness, as well as consumer knowledge of the event-sponsor link (Grohs \& Reisinger, 2014, p. 1020).

Awareness of the sponsor's participation is important because awareness must be achieved first in order to set the stage for the attainment of other sponsorship objectives related to affect and behavioural outcomes, such as enhancing image, influencing intent to behave, achieving image transfer, enhancing sponsor associations and increasing sales (Biscaia et al, 2013; Crompton, 2004; Ko et al., 2008). To move to the affect/behavior level, consumers must first be aware of what the sponsor is supporting before they create an opinion. Biscaia et al.'s study (2014) of consumer recall of sponsor involvement at a Portuguese professional football 
Running head: Title Sponsorship

game, found that more than $82 \%$ of respondents were able to recall the correct sponsor without any prompting.

Title sponsorship is typically expected to provide a higher return on investment due to its higher cost (Cameron, 2008). This means title sponsorship is often considered to be more challenging to sell than other sponsorships except for the largest and most attractive NFP properties with charitable components or causes that are important to many, such as cancer, heart disease and children's health. Thus, our third hypothesis to test is as follows:

H3: The Corporation who is a title sponsor will (a) receive higher evaluations than the NFP who owns the sport event, as well as (b) suppress NFP's evaluations over time.

The evaluation of a title sponsorship should provide insights to not only the sponsor but to the property as well. According to Performance Research (2012), although many sponsors are creatively getting involved past the evaluation of traditional activations (e.g., signage, public announcement), they are still struggling to evaluate not only the return on investment but also the effects of the sponsorship on their specific objectives. The academic literature supports this (O’Reilly \& Madill, 2012) and industry research shows that Canadian properties are underdelivering to their sponsors on many of their sought outcomes (CSLS, 2016; 2018) and servicing (O’Reilly \& Huybers, 2015). According to Walraven, Bijmolt and Koning (2014), sponsorship managers do believe that the longer the sponsorship, the better the brand equity. One could infer an advantage to title sponsorship where the exposure of the sponsorship is typically higher, which is tested with the fourth hypothesis.

H4: The Corporation who is a title sponsor will (a) receive higher evaluations than those organizations who are involved in a lower-profile sponsorship, as well as (b) suppress their evaluations over time. 
Running head: Title Sponsorship

\section{Method}

To test these hypotheses, the authors of this study analysed data from evaluations undertaken from each of the six years of SDIC: 2010, 2011, 2012, 2013, 2014 and 2015. For the 2013, 2014 and 2015 editions, held each November, the event was known as RBC SDIC, presented by ParticipACTION, CBC and True Sport. Data from 2010-12 is compared to 2013-15 to understand the influence of RBC's title sponsorship.

The data were collected around each of the six years of SDIC and analysed to respond to the research questions. To control for extraneous factors year-over-year, data were collected in the same timeframe (October) each year, immediately following SDIC, where respondents were asked to respond about the property and their activities undertaken in SDIC that year. Each year's evaluation was undertaken by an independent research agency, IMI International [http://www.consultimi.com/] from three different sources. First, a representative (by age and gender) national survey of Canadians between the ages of 13 and 65 (controlling for gender, age, region and language) was undertaken in each of the 6 years from 2010 to 2015. The sample size ranged from a low of 630 in 2011 to a high of 1,220 in 2013 (See Table 1) with each year of the survey independent in terms of respondents. If an oversample bias existed on gender or region, the survey respondents were weighted back to their national representation. Where applicable, data from all six years were compared. All comparisons are based on a $95 \%$ confidence interval.

Second, a survey of both event organizers (approximately 400 respondents annually) and ParticipACTION grant recipients (approximately 80 each year) was analysed. The studies were implemented starting in 2012 and in each of the following 3 years (to 2015). The event organizer survey helped to evaluate the overall event and allowed for an additional measurement of the objectives, while the survey of grant recipients allowed for an understanding of how awareness 
Running head: Title Sponsorship

for the grant program was generated. Finally, several secondary sources (i.e., event registration from website, broadcast and digital tracking, and social media tracking) were obtained to provide additional insights to the amount of event reach and awareness through all media.

\section{Results}

The results of the three data collection methods are organized under four hypotheses. All perceptual differences in this study were measured using Fisher Exact Chi Square Test. H1 proposes that the Corporation will receive positive evaluations as a title sponsor of a causerelated event. RBC acquired SDIC's title sponsorship in 2013, the first of a three-year partnership. Table 1 provides several key metrics around RBC's role as title sponsor of SDIC, from both the survey of Canadians and the survey of event operators. Among lay Canadians, aided awareness remained steady from 2013 to 2015 at 28\%. Unaided awareness and awareness of title sponsorship (among those aware of SDIC) reported by respondents indicate an increase in 2015 over 2014 (20\% from 14\% at $\mathrm{p}<.05)$. Among those aware of RBC sponsorship, favorability and consideration for RBC products and services enhanced in 2015 as compared to 2014 (49\% to $56 \%$ and $37 \%$ to $41 \%$ respectively at $\mathrm{p}<.05)$.

Table 1 further displays results from the sub-sample of respondents who were aware of the sponsorship. This group reported high levels of consideration in 2015 for changing banking services (58\%), for banking with RBC more (73\%), for investments (63\%), and for RBC credit cards $(65 \%)$, although these perceptions were either similar or lower to perceptions in 2014.

The event organizers were similarly asked to rate the influence of the RBC sponsorship on a variety of variables. In 2015, a majority (61\%) supported SDIC's promotion of active living and sport participation due to the RBC sponsor, the first year this question was asked. The event organizers also noted strong favorability due to the RBC sponsorship on (i) perception of SDIC 
Running head: Title Sponsorship

in 2015 (59\%), (ii) intention to register a SDIC event next year (58\%), and (iii) SDIC's ability to generate local and national media attention (51\%). The 2015 results of these reported perceptions were statistically higher than 2014 at $\mathrm{p}<.05$.

\section{***INSERT TABLE 1 ABOUT HERE***}

In 2014 and 2015, the survey of Canadian respondents asked additional questions related to sponsorship equity (i.e., the value of the sponsorship for RBC as title sponsor) based on six attributes (as reported in Table 2). These attributes were then compared between those respondents who were aware of the RBC sponsorship ( $n=126$ in $2014 ; n=135$ in 2015 ) to those who were not aware ( $n=1,076$ in 2014; $n=945$ in 2015). Each difference was significant at the $\mathrm{p}<.05$ level with all of the 'not aware' group being significantly lower than the 'aware' group.

\section{***INSERT TABLE 2 ABOUT HERE***}

Thus, it is concluded that the data largely supports $\mathrm{H} 1$.

In $\mathrm{H} 2$, it was proposed that the Corporation who is a title sponsor will enhance the evaluations of the cause-related event as well as the cause. In estimating the findings of the overall Canadian population of 13-65-year olds (estimated to be about 24 million), about 10 million Canadians were aware of SDIC in 2015 and about 4.3 million were engaged in the event. Of those engaged in $2015,62 \%$ were active participants (i.e., they played a sport, volunteered at an event, or attended an event), while $38 \%$ were non-active participants (i.e., wore a jersey on jersey day or watched the broadcast on television). Note that the active participants may also have participated non-actively.

When the 2010-12 average (absence of RBC title sponsorship) is compared with the 2013-15 average (presence of RBC title sponsorship), findings reveal consistently positive 
Running head: Title Sponsorship

perceptions at $p<.05$. Awareness of, and engagement with SDIC enhanced by $5 \%$ and $4 \%$ respectively (see Table 3).

\section{***INSERT TABLE 3 ABOUT HERE***}

Table 4 outlines the results from the event organizer/grant recipient surveys. These surveys were first undertaken in 2012 and replicated in 2013, 2014 and 2015 including the three years of the RBC title sponsorship. Of note are the positive results regarding satisfaction of involvement in SDIC by event organizer and grant recipient stakeholder groups.

\section{***INSERT TABLE 4 ABOUT HERE***}

The secondary sources of data in 2015 provide a snapshot on the scope of SDIC, noting that 289 community-wide events and 2,101 total events/activities were included in SDIC in 2015. The media report estimated that SDIC 2015 achieved 85.5 million media impressions. In 2013 (the most recent data available), the SDIC website attracted 38,273 unique views, 1,731 streaming views, and more than 115,000-page views.

Finally, in Table 5, a change in perceptions among Canadians (13 to 65 years) towards the cause among those aware of SDIC is reported. Intention to be active and healthy increased from $49 \%(2010-12)$ to $57 \%(2013-15)$. Similarly, perception that SDIC contributes to healthy living increased from $74 \%$ to $84 \%$ during the same period. Both changes were statistically significant at $\mathrm{p}<.05$.

\section{***INSERT TABLE 5 ABOUT HERE***}

Thus, findings support $\mathrm{H} 2$.

$\mathrm{H} 3$ and $\mathrm{H} 4$ hypothesize influence of RBC on the perceptions towards organizers and other sponsors. SDIC had partners/sponsors since its inception in 2010. In its first 3 years (2010 to 2012), in addition to ParticipACTION (the founding NFP organisation), two media partners 
Running head: Title Sponsorship

(CBC in English and Radio-Canada in French), two government partners (Government of Canada, Government of British Columbia), and one sector partner (TrueSport, a NFP organisation whose mandate is clean, fair sport) were all involved.

With reference to $\mathrm{H} 3$ (see Table 6), RBC sponsorship awareness levels were consistently lower than ParticipACTION across the three years (for example, $28 \%$ versus $38 \%$ in 2015 ) but better than True Sport (for example, 28\% versus 9\% in 2015). The results are somewhat different in terms of trends in perceptions for the partner organizations. Upon RBC acquiring title sponsorship, awareness of ParticipACTION decreased from 47\% in 2012 to $37 \%$ as average of 2013-15 ( $p<.05)$, although awareness of True Sport increased from 3\% in 2012 to $7 \%$ as average of 2013-15 ( $<<.05)$. H3 was thus partially supported.

\section{***INSERT TABLE 6 ABOUT HERE***}

To assess H4, perceptions of RBC were compared with other lower-level sponsors. As noted in Table 7 and Figure 1, the overall perceptions towards sponsors are positive. Although the awareness levels ranged from 25\%-30\% across six years with a non-significant trend, the respondent consideration for sponsor products and services and sponsor favorability improved. Consideration for products and services increased from 30\% (average of 2010-2012) to $47 \%(2013-2015, \mathrm{p}<.05)$. During the same period, sponsor favourability increased from $34 \%$ to $58 \%(\mathrm{p}<.05)$.

As reported in Table 8, for survey respondents who indicated that they were aware of SDIC, awareness levels for each of the sponsors varied considerably by organization and by year. In the case of RBC, as title sponsor, aided awareness remained steady at $28 \%$, while the lead media partner and broadcaster, CBC, had the highest results every year except 2014, when the French media partner/broadcaster, Radio-Canada, was highest. Specific to the title 
Running head: Title Sponsorship

sponsorship which began in 2013, a comparison of the 2013 data versus 2012 (as reported in Table 8) supports an argument that the addition of RBC as the title sponsor detracted from the awareness levels of the other partners. Based on Fisher's exact chi-square test, four of the partners experienced significant declines in 2013: CBC was down to 44\% in 2013 from 60\% in $2012(\mathrm{p}<.01)$ and remained at those levels in 2014 and 2015, BC Healthy Families went down to $19 \%$ from $43 \%(\mathrm{p}<.01)$ and remained steady at those levels in 2014 and 2015, and Radio Canada went down to $34 \%$ from $46 \%(\mathrm{p}<.01)$ which increased to $43 \%$ in 2014 but declined to its lowest level of $30 \%$ in 2015 . Government of Canada did not show significant change although it went down to $28 \%$ from $34 \%$ in 2013 , increased to $36 \%$ in 2014 but declined to $29 \%$ in 2015 .

When these perceptions were compared between 2012 and an average of 2013-15, all sponsors except Government of Canada displayed significant decline. CBC awareness declined from $60 \%$ (average of $2010-12$ ) to $42 \%$ (average of $2013-15$ ); Radio-Canada Sports from $46 \%$ to $35 \%$; and Government of British Columbia from $43 \%$ to $20 \%$; all at $\mathrm{p}<.05$. Government of Canada awareness declined too (34\% to $31 \%)$ but the difference was not statistically significant.

Despite these declines, the lower-level sponsors still performed better than the title sponsor. H4 was thus partially supported.

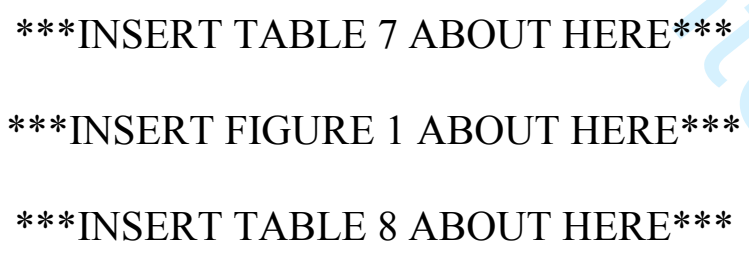

\section{Discussion}

In 2010, ParticipACTION and SDIC set out to increase awareness of the benefits of sport and provide Canadian communities the opportunity to celebrate sport. In 2013 , RBC became the title sponsor of RBC SDIC. RBC SDIC was a successful (increases over time in awareness, 
Running head: Title Sponsorship

intentions and participation) cause-related sport event (White et al., 2016; Luciani et al., 2016) that added a title sponsor following its third edition, providing the context for this research on title sponsorship of cause-related sport events. Three separate surveys were conducted annually around SDIC to provide the data to test four hypotheses.

Overall, the key contribution of this research is its finding that title sponsorship status has benefits to the sponsor, to such an extent that they can detract from the benefits provided to other (non-title) sponsors of the same property thus building on the limited previous work specific to title sponsorship (Clark, Cornwell \& Pruitt, 2008). The results further provide insights into perceptions of event and the cause (physical activity and youth) as well as sponsorship outcomes for RBC. Results support that consumers place value in corporations who support events and causes that are important to them and that reflect Canadian heritage. Notably, results indicate that the RBC title sponsorship was shown to increase the trust that Canadian consumers have in RBC as a sponsor. In addition to supporting the notion that title sponsorship is a distinct context from typical sponsorship (Clark, Cornwell \& Pruitt, 2008), results also support that sponsorship fit is a key attribute in title sponsorship (Madill \& O'Reilly, 2010) and note the importance of CRM in a title sponsorship (Simpson, Lefroy \& Tsarenko, 2011). From a practical perspective, these results infer that title sponsorship is a high value proposition for a sponsor who fits with the cause, has a plan to activate the investment using CRM and has clear communicated status as title.

The first hypothesis explored the specific benefits to the title sponsor, RBC. Results provide strong evidence of the awareness value provided to a title sponsor and demonstrate that some benefits (for example, unaided awareness) increased over the 3-year title sponsorship. Sponsorship outcomes for RBC were positive and supported previous literature related to sponsorship's ability to build a relationship between a corporation and a consumer. First, it has 
Running head: Title Sponsorship

been established in previous research that consumers put value in corporations who support events and causes that are important to them (Westberg \& Pope, 2014), which is extended to the specific content of title sponsorship and supported by the results here (Table 5). Second, specific to the Canadian context, industry research has shown that Canadians put high value in sponsors who reflect the heritage of Canada and who are seen to be giving back for a better future (Ipsos, 2016), which is a benefit provided to RBC via this sponsorship. Finally, and possibly most important from a marketing perspective, RBC sponsorship increases trust among Canadian consumers, and trust will likely enhance firm-consumer marketing relationship (Danthine \& Jin, 2007; Sirdeshmukh, Singh, \& Sabol, 2002).

$\mathrm{H} 2$ was supported by the findings suggesting that having a title sponsor will improve the evaluations of the event and the cause. Although there could be other influencers to consider and these are the results related to a single title sponsor, the results on these outcomes (support of the event and support of the cause) were significantly higher after the RBC title sponsorship came into effect. The event organizers survey results further supported the finding. These results support the notion that title sponsorship, with the right title sponsor (fit with the cause and the property (O'Reilly \& Madill, 2012)), benefits both the event and the cause. Practically, this further enforces the value of a title sponsorship above a typical sponsorship for both sponsor and property.

H3-H4 explored title sponsorship and how it differs from other levels of sponsorship. Findings revealed that, for all levels of sponsorship the asset value of SDIC (as a cause-related sport event) was substantiated and supported. This fits with the previous studies on sponsorship evaluation and further reinforces that it is the activation of a sponsorship asset that largely determines its success (O’Reilly \& Lafrance Horning, 2013). Second, in terms of unaided 
Running head: Title Sponsorship

awareness, the title sponsor, RBC had a series of better performance measures than for most of the other partners in 2013, 2014 and 2015, a notable finding given that the other partners associated with SDIC since 2010 and that many of these partners had strong ties to SDIC. This suggests an 'awareness advantage' for the title sponsor over other partners. Third, throughout the three years of assessment with $\mathrm{RBC}$ as title sponsor, most respondents were aware of $\mathrm{RBC}$ as a sponsor and many knew that RBC was the title sponsor. Fourth, and perhaps the most important finding was that awareness levels of ParticipACTION dropped from $47 \%$ to $37 \%(\mathrm{p}<.01)$ from 2012 to 2013-15 when the RBC title sponsorship launched, suggesting that perhaps some confusion over naming when a title sponsor joins. This apparent disadvantage needs to be weighed against the infusion of financial and in-kind support. Finally, and further evidence of the importance of activation and reach (O’Reilly \& Madill, 2012), are the high levels of awareness for the media partners (CBC and Radio Canada). Thus, in responding to $\mathrm{H} 3-\mathrm{H} 4$, the data suggest that title sponsor status facilitates the ability to increase awareness for the sponsor, but that success requires effective activation and a strong property to achieve greater return than other sponsorship levels.

Although this research study is exploratory, in terms of benefits for practice, it highlights the need for continued evaluation at multiple levels of sponsorship (and the title sponsorship level specifically) and provides important consideration for NFP organisations, and potential sponsors, to consider. Notably, for managers of NFP organisations seeking to launch or support events related to their cause of interest, the decision to accept a title sponsorship needs to be closely considered given the possible outcome of reduced awareness for the NFP organisation. Consideration of the cost-benefit of title sponsorship is recommended. Similarly, the reach of the event is shown here to be important (i.e., the number of local events within SDIC), which is 
Running head: Title Sponsorship

something NFP organisations should consider when creating such a property. For corporate sponsors for whom an increased association with a NFP organisation or a specific cause could be of benefit, the title sponsorship of a far-reaching cause-related sport event should be an alternative to consider. For corporations seeking to market their brand, products and/or services to target markets, the title sponsorship with a cause and a property that would be appealing to those markets, should be an important alternative to consider.

The study has a few limitations. First, due to limitations of data analysis is restricted to descriptive statistics and lower-order analysis and does not build a model amongst key variables. This is something that future research should address by collecting data that allows for the confirmation of the exploratory findings and addresses more closely the four hypotheses. Second, the data on participants were collected indirectly from the event organizers. Since the occurrence of physical activity is an important metric of SDIC's success, collecting data based on direct and systematic observation would enhance the evaluation process and provide a more accurate understanding of audience participation in the event. Data need to be collected in the future to understand audience demographic profile, their physical activity status, and the match with RBC consumer profile. Third, the study investigated awareness, favourability, and behavioural potential for title and secondary sponsors. It did not compare the increment in value for these brands because of their sponsorship decision. Future research should explore the improvement in brand value as a result of sponsorship activities.

Fourth, an assumption was made that changes in perceptions 2013 onwards were solely due to $\mathrm{RBC}$ acquiring the title sponsorship of SDIC, which may not be true. Other factors such as the year-over-year growth of the event, the increasing importance of the cause, or changes in the external environment over time, may have influenced these changes. 
Running head: Title Sponsorship

Finally, the percentage of Canadians who were unaware of SDIC were high. This reflects the weakness of the RBC SDIC campaign and reduces the importance of findings and influence of title sponsorship of a cause-related sport event.

\section{Conclusion}

This research provides strong support for title sponsorship of a cause-related sport event as a consideration for corporations seeking to market products to people who have an affinity to that cause. If the brand is seeking an investment that also has philanthropic and CSR outcomes, then these types of events and the title sponsorship status increase incrementally. For causerelated sport properties seeking resources to support their event and/or cause, title sponsorship is an appropriate tactic to consider, particularly if there are brands who fit with the event property and the cause. 
Running head: Title Sponsorship

\section{References}

Babiak, K. M. \& Sheth, H. (2010). Beyond the game: Perceptions and practices of corporate social responsibility in the professional sport industry. Journal of Business Ethics. 91 433450 .

Berger, I.E., Hernandez, T., O’Relly, N., Parent, M.M., Seguin, B. (2008). Determinants of sport participation among Canadian adolescents. Sports Management Review. 11. 277-307.

Biscaia, R., Correia, A., Ross, S., \& Rosado, A.F. (2014). Sponsorship effectiveness in professional sport: an examination of recall and recognition among football fans. International Journal of Sport Marketing \& Sponsorship, 16(1), 7-23.

Biscaia, R., Correia, A., Rosado, A.F., Ross, S, \& Maroco, J. (2013). Sport sponsorship: the relationship between team loyalty, sponsorship awareness, attitude toward the sponsor, and purchase intentions. Journal of Sport Management, 27(2), 88-302.

Cameron, N. (2008) Understanding sponsorship and its measurement implications. Journal of Sponsorship. 2(2), 131-139.

Clark, J.M., Cornwell, B.T. \& Pruitt, S.W. (2008). The impact of title event sponsorship announcements on shareholder wealth. Marketing Letters. 20(2), 169-182.

CCSIS (2013). Cone Communications Social Impact Study: The next cause evolution. Cone Communications: Public Relations \& Marketing.

CSLS (2016). Canadian Sponsorship Landscape Study, $10^{\text {th }}$ annual version; downloaded February $20^{\text {th }}, 2016$ from www.sponsorshiplandscape.ca.

CSLS (2018). Canadian Sponsorship Landscape Study, $11^{\text {th }}$ annual version; downloaded July $28^{\text {th }}, 2018$ from www.sponsorshiplandscape.ca.

Danthine, J., \& Jin, X. (2007). Intangible capital, corporate valuation and asset pricing. Economic Theory, 32(1), 157-177.

d'Astous, A. \& Legendre, A. (2008). Understanding consumers' ethical justifications: a scale for appraising consumers' reasons for not behaving ethically, Journal of Business Ethics. 87, 255-268.

Delia, E. B. (2014). Subconscious (un)attachment to a sponsor: an irrational effect of facility naming rights. Journal of Sport Management. 28, 551-564

Disabled Sports USA. (2015). Events. Retrieved October 23, 2016, http://www.disabledsportsusa.org/events/ 
Running head: Title Sponsorship

Grohs, R. \& Reisinger, H. (2014). Sponsorship effects on brand image: The role of exposure and activity involvement, Journal of Business Research, 67, 1018-1025.

Groza, M.D., Cobbs, J. \& Schaefers, T. (2012). Managing a sponsored brand the importance of sponsorship portfolio congruence. International Journal of Advertising, 31(1), 63-84.

Gourville, J. T. \& Rangan, V. K. (2004). Valuing the cause marketing relationship. California Management Review, 47(1), 38-57.

Gwinner, K.P., Larson, B.V. \& Swanson, S.R. (2009). Image transfer in corporate event sponsorship: assessing the impact of team identification and event-sponsor fit. International Journal of Management \& Marketing Research, 2(1), 1-15.

IEG (2016). IEG Sponsorship Report, Feb 29 ${ }^{\text {th }}, 2016$; downloaded from www.sponsorship.com.

Ipsos (2016). Most Valuable Property Study, Syndicated Study.

Irmak, C., Jayachandran, S. \& Robinson, S. R. (2012). Choice of cause in cause-related marketing. Journal of Marketing, 76, 126-139.

Lacey, R., Close, A.G. \& Finney, R.Z. (2010). The pivotal roles of product knowledge and corporate social responsibility in event sponsorship effectiveness, Journal of Business Research, 63, 1222-1228.

Lee, S., Harris, J. \& Lyberger, M. (2011). Recreational golfers' attitudes and awareness of sponsorship: a case study of the 2008 Ryder Cup. Managing Leisure, 16(3), 13-24.

Lii, Y., Wu, K. \& Ding, M. (2011). Doing good does good? Sustainable marketing of CSR and consumer evaluations. Corporate Social Responsibility and Environmental Management. 20, $15-28$.

Luciani, A., White, L., Berry, T.R., Deshpande, S., Latimer-Cheung, A.E., O’Reilly, N., Spence, J.C., Rhodes, R.E., Tremblay, M.S., \& Faulkner, G. (2016). Sports Day in Canada: examining the benefits for event organizers (2010-2013). International Journal of Health Promotion and Education, DOI: 10.1080/14635240.2016.1217164

Madill, J. \& O’Reilly, N. (2010). Investigating social marketing sponsorships: Terminology stakeholders, and objectives. Journal of Business Research, 63, 133-139.

Meenaghan, T. (2013). Measuring sponsorship performance: challenge and direction, Psychology \& Marketing, 30(5), 385-393.

Navarro, E. (2005). Government funding for charities: when it declines, the charities lose twice. Retrieved October 23, 2016, http://www.charitynavigator.org/index.cfm?bay=content.view\&cpid=281\#.VPNzr-GHyQc 
Running head: Title Sponsorship

Neuman, W.L. (2011). Social Research Methods: Qualitative and Quantitative Approaches, $7^{\text {th }}$ Edition, Pearson Education, Boston, MA, USA.

Nufer, G. \& Bühler, A. (2010). How effective is the sponsorship of global sports events? A comparison of the FIFA World Cups in 2006 and 1998. International Journal of Sports Marketing \& Sponsorship, 11(4), 303-319.

O’Reilly, N. \& Lafrance Horning, D. L. (2013). Leveraging sponsorship: the activation ratio. Sports Management Review, 16(4), 424-437.

O’Reilly, N. \& Huybers, T. (2015). “Servicing in Sponsorship: A Best-Worst Scaling Empirical Analysis", Journal of Sport Management, 29(2), 153-169.

O’Reilly, N. \& Madill, J. (2012). The development of a process for evaluating marketing sponsorships. Canadian Journal of Administrative Sciences, 29(1), 50-66.

PriceWaterhouseCoopers (2010). Back on Track? The Outlook for the Global Sports Market to 2013. Retrieved December 30, 2014, from http://www.pwc.com/gx/en/entertainmentmedia/pdf/Global-Sports-Outlook.pdf

Polonsky, M.J. \& Speed, R. (2000), Linking sponsorship and cause-related marketing: Complementarities and conflicts. European Journal of Marketing, 35(11/12), 1361-1385.

RiskVentures (2014). Philanthropy. Retrieved October 23, 2016, https://www.rizkventures.com/philanthropy/

Rozensher, S. (2013). The growth of cause marketing: Past, current, and future trends. Journal of Business \& Economics Research, 11(4), 181-186.

Simpson, D., Lefroy, K. \& Tsarenko, Y. (2011). Together and apart: Exploring structure of the corporate-NPO relationship. Journal of Business Ethics, 101, 297-311.

Sirdeshmukh, D., Singh, J., \& Sabol, B. (2002). Consumer trust, value, and loyalty in relational exchanges. Journal of Marketing, 66(1), 15-37.

Sports Day (2016). Sports Day in Canada 2015 Results, February 2016; internal research document provided by ParticipACTION and IMI.

Walraven, M., Koning, R.H., Bijmolt, T.H.A., \& Los, B. (2016). Benchmarking sports sponsorship performance: Efficiency assessment with data envelopment analysis. Journal of Sport Management, 30(4), 411-426.

Walraven, M., H, T., Bijmolt, A. \& Koning, R. H. (2014). Dynamic effects of sponsoring: how sponsorship awareness develops over time. Journal of Advertising, 43(2), 142-154. 
Running head: Title Sponsorship

Westberg, K. \& Pope, N. (2014). Building brand equity with cause-related marketing: A comparison with sponsorship and sales promotion. Journal of Marketing Communications, 20(6), 419-437.

White, L., Luciani, A., Berry, T., Deshpande, S., Latimer-Cheung, A., O'Reilly, N., Rhodes, R., Spence, J. C., Tremblay, M., \& Faulkner, G. (2016). Sports day in Canada: A longitudinal evaluation. International Journal of Health Promotion and Education, 54(1), 12-23.

$10.1080 / 14635240.2015 .1050122$

Yin, R.K. (2013). Applications of Case Study Research. 2nd ed. London: Sage Publications. 
Running head: Title Sponsorship

\section{Table 1}

\section{Title Sponsor Key Metrics}

\begin{tabular}{|c|c|c|c|}
\hline Metric Related to Title Sponsorship & $2013^{\wedge}$ & 2014 & 2015 \\
\hline Among all Canadians & $\mathrm{N}=1220$ & $\mathrm{~N}=1202$ & $\mathrm{~N}=1080$ \\
\hline Aware (unaided) & $16 \%$ & $14 \%$ & $20 \% *$ \\
\hline Aware (aided) & $28 \%$ & $28 \%$ & $28 \%$ \\
\hline "Saw a promotion at RBC branch" & & $7 \%$ & $7 \%$ \\
\hline Aware of Title Sponsor (among those aware of SDIC) & $16 \%$ & $10 \% *$ & $16 \% *$ \\
\hline+2 & & & \\
\hline Among Canadians who are aware of RBC sponsorship & $\mathrm{N} / \mathrm{A}$ & $\mathrm{N}=126$ & $\mathrm{~N}=135$ \\
\hline Favourable to RBC Brand & $\mathrm{N} / \mathrm{A}$ & $49 \%$ & $56 \% *$ \\
\hline Consider RBC products and services & N/A & $37 \%$ & $41 \% *$ \\
\hline 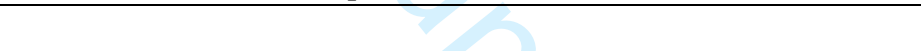 & & & \\
\hline \multicolumn{4}{|l|}{ Among those aware of RBC sponsorship } \\
\hline Consider changing banking services & $68 \%$ & $57 \% *$ & $58 \%$ \\
\hline Consider more banking with RBC & $77 \%$ & $73 \% *$ & $73 \%$ \\
\hline Consider RBC for my investments & $59 \%$ & $63 \% *$ & $63 \%$ \\
\hline Consider RBC credit cards & $67 \%$ & $69 \% *$ & $65 \% *$ \\
\hline Among Event Organizers & $\mathrm{N}=402$ & $\mathrm{~N}=292$ & $\mathrm{~N}=337$ \\
\hline $\begin{array}{l}\text { Promotes active living and sport participation messages } \\
\text { in Canada due to RBC sponsorship }\end{array}$ & $\mathrm{N} / \mathrm{A}$ & $\mathrm{N} / \mathrm{A}$ & $61 \%$ \\
\hline Perception of SDIC due to RBC sponsorship & $48 \%$ & $44 \% *$ & $59 \% *$ \\
\hline $\begin{array}{l}\text { Intend to register a SDIC event next year because of } \\
\mathrm{RBC} \text { sponsorship }\end{array}$ & $48 \%$ & $44 \% *$ & $58 \% *$ \\
\hline $\begin{array}{l}\text { Will generate local/national media attention because of } \\
\text { RBC sponsorship }\end{array}$ & $48 \%$ & $43 \% *$ & $51 \% *$ \\
\hline
\end{tabular}

Source: IMI International Annual Survey, IMI Survey of Event Organizers

$\wedge \mathrm{RBC}$ joins as title sponsor

* denotes a significant change from the previous year $(\mathrm{p}<.05)$ based on Fisher's Exact Chi Square Test 
Running head: Title Sponsorship

\section{Table 2}

\section{RBC Sponsorship Equity Measures}

\begin{tabular}{|l|c|c|c|c|}
\hline \multirow{2}{*}{ Equity Question } & \multicolumn{2}{|c|}{$\mathbf{2 0 1 4}$} & \multicolumn{2}{|c|}{$\mathbf{2 0 1 5}$} \\
\cline { 2 - 4 } & $\begin{array}{c}\text { Not aware of } \\
\text { RBC Sponsorship }\end{array}$ & $\begin{array}{c}\text { Aware of RBC } \\
\text { Sponsorship }\end{array}$ & $\begin{array}{c}\text { Not aware of RBC } \\
\text { Sponsorship }\end{array}$ & $\begin{array}{c}\text { Aware of RBC } \\
\text { Sponsorship }\end{array}$ \\
\cline { 2 - 4 } & $\mathrm{N}=1,076$ & $\mathrm{~N}=126$ & $\mathrm{~N}=945$ & $50 \%$ \\
\hline $\begin{array}{l}\text { RBC is a strong believer that physical } \\
\text { activity is important for children }\end{array}$ & $40 \%$ & $62 \% *$ & $59 \% *$ \\
\hline $\begin{array}{l}\text { RBC contributes to the well-being of } \\
\text { children }\end{array}$ & $35 \%$ & $61 \% *$ & $36 \%$ & $59 \% *$ \\
\hline $\begin{array}{l}\text { RBC supports events and causes that are } \\
\text { important to my community }\end{array}$ & $33 \%$ & $58 \% *$ & $33 \%$ & $58 \%$ \\
\hline $\begin{array}{l}\text { RBC reflects Canadian values in the way } \\
\text { it conducts its affairs }\end{array}$ & $32 \%$ & $49 \% *$ & $33 \%$ & $55 \% *$ \\
\hline $\begin{array}{l}\text { RBC helps Canadian communities build } \\
\text { a better future }\end{array}$ & $32 \%$ & $57 \% *$ & $32 \%$ & $54 \% *$ \\
\hline RBC is a company I trust & $29 \%$ & $48 \% *$ & $29 \%$ & $53 \% *$ \\
\hline
\end{tabular}

Source: IMI International Annual Survey

* denotes a significant difference between the aware and not aware groups $(\mathrm{p}<.05)$ of each year based on Fisher's Exact Chi Square Test 
Running head: Title Sponsorship

\section{Table 3}

\section{SDIC Perceptions}

\begin{tabular}{|l|c|c|c|c|c|c|c|c|}
\hline \multicolumn{1}{|c|}{ Metric/Item } & $\mathbf{2 0 1 0}$ & $\mathbf{2 0 1 1}$ & $\mathbf{2 0 1 2}$ & $\mathbf{2 0 1 3}^{\wedge}$ & $\mathbf{2 0 1 4}$ & $\mathbf{2 0 1 5}$ & $\begin{array}{c}\text { Average of } \\
\mathbf{2 0 1 0 - 2 0 1 2}\end{array}$ & $\begin{array}{c}\text { Average of } \\
\mathbf{2 0 1 3 - 2 0 1 5}\end{array}$ \\
\hline Canadians (13 to 65 years) & 863 & 630 & 731 & 1,220 & 1,202 & 1,080 & & \\
\hline Total SDIC awareness & $28 \%$ & $47 \%$ & $42 \%$ & $47 \%$ & $38 \%$ & $44 \%$ & $38 \%$ & $43 \%^{*}$ \\
\hline Total SDIC engagement & $11 \%$ & $23 \%$ & $12 \%$ & $24 \%$ & $15 \%$ & $18 \%$ & $15 \%$ & $19 \% *$ \\
\hline
\end{tabular}

Source: IMI International Annual Survey

$\wedge$ RBC joins as title sponsor

* denotes a significant difference between the averages of 2010-2012 and 2013-2015 (p<.05) based on Fisher's Exact Chi Square Test 
Running head: Title Sponsorship

Table 4

Perceptions towards SDIC event

\begin{tabular}{|c|c|c|c|c|c|}
\hline \multicolumn{6}{|c|}{ Event Organizers } \\
\hline Metric/Item & 2012 & $2013^{\wedge}$ & 2014 & 2015 & $\begin{array}{c}\text { Average } \\
\text { of } 2013- \\
2015 \\
\end{array}$ \\
\hline Respondents & 413 & 402 & 292 & 337 & \\
\hline Very/somewhat satisfied with SDIC & $87 \%$ & $93 \%$ & $97 \%$ & $96 \%$ & $95 \% *$ \\
\hline Very/somewhat satisfied with promotional tools/support & $91 \%$ & $90 \%$ & $74 \%$ & $69 \%$ & $76 \% *$ \\
\hline Agree that organization benefitted from SDIC & $78 \%$ & $91 \%$ & $87 \%$ & $98 \%$ & $93 \% *$ \\
\hline Believe that SDIC was a positive experience & $90 \%$ & $95 \%$ & $90 \%$ & $97 \%$ & $94 \%$ \\
\hline Likely to register for another event & $96 \%$ & $97 \%$ & $97 \%$ & $97 \%$ & $97 \%$ \\
\hline Would recommend SDIC to another organization & $88 \%$ & $97 \%$ & $95 \%$ & $95 \%$ & $96 \% *$ \\
\hline Believe that SDIC has a positive effect on the community & $86 \%$ & $83 \%$ & $98 \%$ & $99 \%$ & $94 \% *$ \\
\hline
\end{tabular}

\begin{tabular}{|c|c|c|c|c|c|}
\hline \multicolumn{6}{|c|}{ Grant Recipients } \\
\hline Metric/Item & 2012 & $\mathbf{2 0 1 3}^{\wedge}$ & 2014 & 2015 & $\begin{array}{c}\text { Average } \\
\text { of 2013- } \\
2015\end{array}$ \\
\hline Respondents & 44 & 82 & 84 & 120 & \\
\hline Reported their organization benefitted from SDIC & $78 \%$ & $93 \%$ & $89 \%$ & $95 \%$ & $93 \% *$ \\
\hline Increased awareness/interest in organization & $34 \%$ & $53 \%$ & $53 \%$ & $68 \%$ & $59 \% *$ \\
\hline Increased awareness/interest in their sport programs & $39 \%$ & $47 \%$ & $52 \%$ & $64 \%$ & $56 \% *$ \\
\hline Increased participation/registration in sport programs & $33 \%$ & $33 \%$ & $28 \%$ & $37 \%$ & $33 \%$ \\
\hline Likely to apply for grant in the future & $88 \%$ & $100 \%$ & $91 \%$ & $100 \%$ & $97 \% *$ \\
\hline Attracted local media attention & $13 \%$ & $19 \%$ & $21 \%$ & $32 \%$ & $25 \% *$ \\
\hline Facilitated new or strengthened existing partnerships & $22 \%$ & $25 \%$ & $36 \%$ & $47 \%$ & $37 \% *$ \\
\hline
\end{tabular}

Source: IMI International Surveys - Event Organizers and Grant Recipients Surveys

$\wedge$ RBC joins as title sponsor

* denotes a significant difference between 2012 and the average of 2013-2015 (p<.05) based on Fisher's Exact Chi Square Test 
Running head: Title Sponsorship

\section{Table 5}

Perceptions towards Active Living (among those aware of SDIC)

\begin{tabular}{|l|c|c|c|c|c|c|c|c|}
\hline \multicolumn{1}{|c|}{ Metric/Item } & $\mathbf{2 0 1 0}$ & $\mathbf{2 0 1 1}$ & $\mathbf{2 0 1 2}$ & $\mathbf{2 0 1 3}^{\wedge}$ & $\mathbf{2 0 1 4}$ & $\mathbf{2 0 1 5}$ & $\begin{array}{c}\text { Average of } \\
\mathbf{2 0 1 0 - 2 0 1 2}\end{array}$ & $\begin{array}{c}\text { Average of } \\
\mathbf{2 0 1 3}-2015\end{array}$ \\
\hline Canadians (13 to 65 years) & 863 & 630 & 731 & 1,220 & 1,202 & 1,080 & & \\
\hline $\begin{array}{l}\text { Increased intention to be active } \\
\text { and healthy }\end{array}$ & $43 \%$ & $54 \%$ & $51 \%$ & $56 \%$ & $58 \%$ & $57 \%$ & $49 \%$ & $57 \%^{*}$ \\
\hline $\begin{array}{l}\text { Agreement that SDIC } \\
\text { contributed to healthy living }\end{array}$ & $68 \%$ & $82 \%$ & $73 \%$ & $82 \%$ & $85 \%$ & $84 \%$ & $74 \%$ & $84 \%^{*}$ \\
\hline
\end{tabular}

Source: IMI International Annual Survey

$\wedge$ RBC joins as title sponsor

* denotes a significant difference between the averages of 2010-2012 and 2013-2015 ( $p<.05)$ based on Fisher's Exact Chi Square Test 
Running head: Title Sponsorship

\section{Table 6}

Title Sponsor and Organizer Awareness (among those aware of SDIC)

\begin{tabular}{|l|c|c|c|c|c|}
\hline \multicolumn{1}{|c|}{ Sponsor } & $\mathbf{2 0 1 2}$ & $\mathbf{2 0 1 3}^{\wedge}$ & $\mathbf{2 0 1 4}$ & $\mathbf{2 0 1 5}$ & $\begin{array}{c}\text { Average of } \\
\mathbf{2 0 1 3 - 2 0 1 5}\end{array}$ \\
\hline RBC (Title) & $\mathrm{n} / \mathrm{a}$ & $28 \%$ & $28 \%$ & $28 \%$ & $28 \%$ \\
\hline ParticipACTION (NFP) & $47 \%$ & $35 \% *$ & $39 \%$ & $38 \%$ & $37 \%^{* *}$ \\
\hline TrueSport (NFP) & $3 \%$ & $6 \%$ & $6 \%$ & $9 \%$ & $7 \% * *$ \\
\hline
\end{tabular}

Source: IMI International Annual Survey

$\wedge \mathrm{RBC}$ joins as title sponsor

* denotes a significant change from the previous year $(\mathrm{p}<.05)$ based on Fisher's Exact Chi Square Test

** denotes a significant change from 2012 to the 2013-2015 average $(\mathrm{p}<.05)$ based on Fisher's Exact Chi Square

Test 
Running head: Title Sponsorship

\section{Table 7}

Sponsor Perceptions (among those aware of SDIC)

\begin{tabular}{|c|c|c|c|c|c|c|c|c|}
\hline Metric/Item & 2010 & 2011 & 2012 & $2013^{\wedge}$ & 2014 & 2015 & $\begin{array}{c}\text { Average of } \\
2010-2012\end{array}$ & $\begin{array}{l}\text { Average of } \\
2013-2015\end{array}$ \\
\hline Canadians (13 to 65 years) & 863 & 630 & 731 & 1,220 & 1,202 & 1,080 & & \\
\hline Sponsor awareness & $25 \%$ & $28 \%$ & $25 \%$ & $29 \%$ & $30 \%$ & $28 \%$ & $26 \%$ & $29 \%$ \\
\hline $\begin{array}{l}\text { Sponsor favourability (average } \\
\text { of all sponsors) }\end{array}$ & $24 \%$ & $34 \%$ & $47 \%$ & $59 \%$ & $56 \%$ & $58 \%$ & $34 \%$ & $58 \% *$ \\
\hline
\end{tabular}

Source: IMI International Annual Survey

$\wedge$ RBC joins as title sponsor

* denotes a significant difference between the averages of 2010-2012 and 2013-2015 ( $\mathrm{p}<.05)$ based on Fisher's Exact Chi Square Test 
Running head: Title Sponsorship

\section{Table 8}

Title and Other Sponsor Awareness (among those aware of SDIC)

\begin{tabular}{|c|c|c|c|c|c|}
\hline 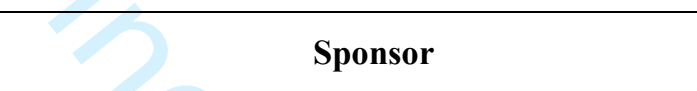 & 2012 & $2013^{\wedge}$ & 2014 & 2015 & $\begin{array}{c}\text { Average of } \\
2013-2015\end{array}$ \\
\hline CBC (other sponsor) & $60 \%$ & $44 \% *$ & $42 \%$ & $40 \%$ & $42 \% * *$ \\
\hline Government of Canada (other sponsor) & $34 \%$ & $28 \%$ & $36 \% *$ & $29 \% *$ & $31 \%$ \\
\hline Government of British Columbia (other sponsor) & $43 \%$ & $19 \% *$ & $20 \%$ & $21 \%$ & $20 \% * *$ \\
\hline
\end{tabular}

Source: IMI International Annual Survey

$\wedge$ RBC joins as title sponsor

* denotes a significant change from the previous year $(\mathrm{p}<.05)$ based on Fisher's Exact Chi Square Test

** denotes a significant change from 2012 to the 2013-2015 average $(p<.05)$ based on Fisher's Exact Chi Square

Test 
Running head: Title Sponsorship

\section{Figure 1}

Sponsor Perceptions in \% (among those aware of SDIC)

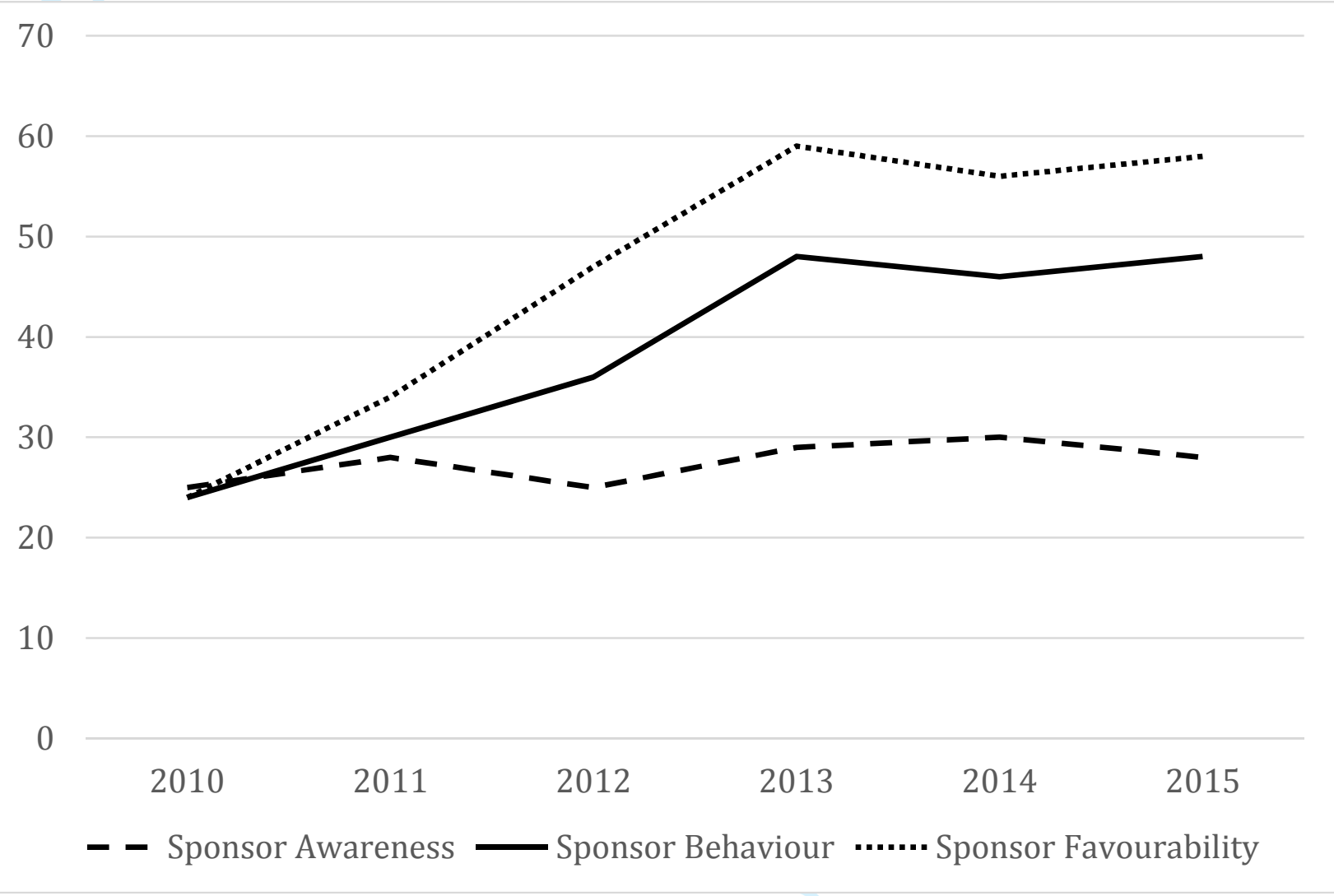

